\title{
The Impact of the Global Financial Crisis on the Co-Integration Relationship between Reit and Stock Markets: A Dynamic Co-Integration Approach
}

\author{
S.Aydın Yüksel ${ }^{1}$, Aslı Yüksel ${ }^{2}$, Ümit Erol $^{2} \&$ Hakkı Öztürk ${ }^{2}$ \\ ${ }^{1}$ Department of Management, Faculty of Economics and Administrative Sciences, Işık University, Istanbul, \\ Turkey \\ ${ }^{2}$ Department of International Finance, Faculty of Economics, Administrative and Social Sciences, Bahçeşehir \\ University, Istanbul, Turkey \\ Correspondence: Hakkı Öztürk, Department of International Finance, Bahçeşehir University, Istanbul, Turkey. \\ Tel: 902-123-810-464. E-mail: hakki.ozturk@eas.bau.edu.tr
}

Received: April 28, 2017

Accepted: May 19, 2017

Online Published: June 15, 2017

doi:10.5539/ijef.v9n7p86

URL: https://doi.org/10.5539/ijef.v9n7p86

\begin{abstract}
The aim of this paper is to analyze the impact of the Global Financial Crisis (GFC) on the co-integration relationship between the REIT and stock market indices using a sample of 10 developed countries. The main tool employed for this purpose is the dynamic co-integration approach. The empirical results strongly suggest that the stock and REIT markets were deeply affected by two successive crises. The first crisis was related to the U.S. subprime problems while the second shock emanated from the European insolvency problems. The shocks led to serious structural breaks in the financial data during the 2007-2012 period. As a result of this and the highly variable nature of the co-integration structure during this period, the conventional and static Johansen tests cannot detect the strong co-integration between the REIT and stock markets which were the result of common negative response of both markets to the successive shocks. Dynamic co-integration approach seems to be a more valid tool to capture the dynamics of the co-integration structure after the GFC. The dynamic approach implies that the destruction of diversification benefits between the REIT and stock markets was essentially a shock related outcome which also implies that the diversification potential between these two markets may still be valid in the absence of shocks.
\end{abstract}

Keywords: REIT, dynamic co-integration, Johansen, global financial crisis

\section{Introduction}

The securitization of real estate (a primary component of household and institutional portfolios) in the form of real estate investment trusts (REIT's) created an attractive alternative to the direct real estate ownership which poses problems such as illiquidity, high transaction costs and costs of acquisition. The market capitalization value of the U.S. REIT's, for example, increased from from $\$ 8.7$ billion at the end of 1990 to $\$ 438$ billion at the end of 2006 (Yang et al., 2012).

The fact that the REIT's can be traded in the financial markets just like stocks implies that they can be used to diversify the risk of asset portfolios. The possibility of diversification depends on the degree of the correlation between the stock and REIT markets. The correct assessment of the correlation between the two markets, however, is not easy. There is, by now, substantial evidence showing that this correlation changes over time (Longin \& Solnik, 1995; Gordon \& Canter, 1999; Wilson \& Zurbruegg, 2003; Liow \& Schindler, 2014). A related question is if the observed correlations between the two markets are basically short-run or long-run in nature. This is important for diversification possibilities since a short-run temporary correlation not extending to the long run implies that the REIT's may not provide diversification benefits in the short-run but such benefits can be realized in the long-run.

The argument for a significant and increasing long-term correlation between the REIT and stock markets stems from two facts. The first is the effect of the globalization which leads to common stochastic trends in the long-run. The second emphasizes the fact that the REIT's started to behave more like stocks after the structural changes in the 1990's (Glascock et al., 2000). As a result; the REIT indices being mutual funds traded in the 
stock markets are expected to co-vary with stock indices and they may embed stock market noise that is not related to the fundamentals driving the real estate returns.

There are, however, counter arguments about the strength of long-term correlations between the stock markets and the REIT markets at a local level (in terms of country-specific correlation). Liow and Schindler (2014) reports that the European and U.S. REIT markets are becoming more integrated with the global and regional stock markets but they are less integrated with their local stock markets. This implies the possibility of diversification at a local (country-specific) level. Hoesli and Okarinen (2012) presents evidence using the data from the U.S, U.K and Australia illustrating the fact that the REIT's are actually close substitutes of direct real estate rather than the stock market in the long-run. Their findings suggest that the REIT performance is more tightly related to the direct real estate performance than to stock market returns.

The empirical literature on the subject also points to a lack of consensus. Liu and Mei (1992), Ambrose et al. (1992), Ling and Naranjo (1999), Quan and Titman (1999) and Peng and Schulz (2013) found that the two markets are correlated while the results of Ibbotson and Siegel (1984), Miles et al. (1990) and Liu et al. (1990) suggest that the two markets are segmented and do not display significant long-term correlation.

These discordant results reported in the literature may be related to the choice of different observation periods and the temporal instability of co-movement in asset returns through time. The traditional tools to detect long-term correlation (co-integration) between the two series are Johansen test and the Engle-Granger test. Both tests assume symmetric adjustment and linearity. These traditional static tests are not able to capture the changing and dynamic nature of the relationships involved.

The economic and financial data usually display structural breaks which poses problems for the validity of conventional Johansen test since the power of the co-integration test is dramatically reduced if a break exists in the co-integration relationship (Gregory \& Hansen, 1996). This issue is especially important for the empirical work covering the last two decades because of the massive structural change initiated by the Global Financial Crisis (GFC) of 2007.

The fact that the GFC caused a significant structural break in the correlation structure is well documented. The empirical tests using either Chow test (Yang et.al., 2012) or Quandt-Andrews breakpoint test (Basse et al., 2009) verifies that there was a massive structural break in 2007. The GFC caused a regime shift significantly altering the nature of the dynamic relationships with possible detrimental effects on the power of the conventional tests (Note 1).

The analysis of the impact of the GFC on the correlation structure between the REIT and stock indices must also consider the unique character of the GFC. It was previously argued that when the equity markets decline in response to negative shocks, REIT's tend to perform better providing diversication benefits (Assaf, 2006). The REIT indices, for example, declined less than non-REIT stocks in the October 1997 crash (Glascock et al., 2004) but this crash was a result of the problems with the automated stock market trading.

The GFC, on the other hand, was related to the serious problems in the real estate sector and it was an extremely strong negative shock of unprecented dimensions. Globally, $\$ 7$ trillion has been wiped off the stock markets during 2008 (Adair et al., 2009) and Case-Schiller index dropped 25\% over two years in the U.S. (Barker, 2009). Empirical evidence presents a consensus view of a substantial increase in the conditional correlation between the stock and REIT indices worldwide. The REIT systematic risk climbed to unusually high levels after the GFC (Devaney, 2012) and the average betas increased from 0.65 to 1.58 as a result of the GFC (Devos et al., 2013).

The significant structural break initiated by the GFC suggests that the market mechanism started to deviate from its previous norm as a result of the unexpected and huge negative shock. Though the investors were theoretically expected to buy REIT's in the face of significant declines in the stock indices; they did not do so because the nature of this real estate based shock was different from the previous shocks. The wealth and credit effects which traditionally explain the causal link between the stock and REIT markets have not worked as expected. Instead, the investors fled from both markets because the investor psychology apparently changed significantly giving way to dominance of what may be called animal spirits and the herding instincts. The flight from both markets led to the observed increase in the correlation between the two markets.

This change in the dynamical structure of both markets unfortunately cannot be traced by conventional tools due to the static nature of these tools. We need an alternative approach which is robust enough to display the change in the dynamics of the market showing how the correlation structure changed in the major markets of the world after the above mentioned structural break.

We then propose the use of dynamic co-integration analysis to empirically assess the time varying nature of the 
co-integration relationships. This is the first study using the dynamic co-integration in this context to the best of our knowledge though this tool was used previously to investigate the changing relationship among different stock markets as, for example, in Guidi and Ugur (2014). The technique was also used by Schindler and Voronkova (2010) for the analysis of REIT indices but their emphasis was on the co-integration among REIT indices rather than the dynamic relationships between the REIT and stock market indices at local levels.

We have chosen a sample of ten developed countries for this purpose. We used daily data and a fairly long observation period from 2001 to 2014. Our purpose is to analyse as closely as possible the evolution of the crisis over time and its subsequent effects on the co-integration relationship. The paper uses dynamic co-integration approach (trace statistics) that scans the whole period through rolling windows. It is an effective tool that clearly shows how the co-integration relations between stock indices and REIT indices varied over time and how they specifically responded to the GFC. It also enables us to see if there were significant differences in the response patterns of different countries.

The rest of the paper is organized as follows: Section 2 describes the data and the details of the methodology. Section 3 presents the empirical results with the relevant tables and figures. Section 4 summarizes the conclusions.

\section{Data and Methodology}

The data set contains the daily observations of Datastream REIT and stock market indices compiled from ten different countries. The source of the data is Datastream. All the countries in the sample are developed countries with highly developed capital markets. The REIT markets included in the set represents nearly $90 \%$ of the public real estate markets in the world. Majority of the countries in the sample are European countries (Germany, France, Italy, the Netherlands, Belgium and the United Kingdom). The remaining four countries (the U.S., Japan, Australia and Canada) represent the leading public real estate and stock markets out of Europe. Most of the countries in the sample have market based financial systems but bank based financial systems are also represented (particularly France and Germany). The representation of bank based systems in the sample enables us to see if there was a significantly different response of the bank based systems to the GFC. It is argued that (Casni \& Vizek, 2014) the reaction of stock and REIT indices to economic news are more synchronized in market based financial systems suggesting a higher degree of integration compared to bank-based financial systems.

The observation period is from January 2, 2001 to February 24, 2014 for all the countries in the sample except Japan. The observation set of Japan covers the period from June 12, 2001 to February 24, 2014. This difference is due to data availability. Daily data is used. We used prices denominated in terms of local currencies (Euro, Yen etc.) rather than converting them into U.S. dollar since the emphasis of the paper is to explore the degree of local (country-specific) correlation and integration between the stock and REIT indices. The index returns which are reported are log returns.

We have chosen August 9, 2007 (August 10 for Japan) as the beginning date of the financial crisis. This is the date when serious payment problems in the three hedge funds of BNP-Paribas were reported (Note 2).

We first applied the conventional static Johansen test (Johansen, 1988) to the full observation set for the 10 countries in the sample after checking the unit root requirements. Following Hall (1989), we specified the VAR lag order such that the error terms were serially uncorrelated and the Akaike Information Criterion (AIC) was minimized. As is well known; this test is based on the statistical significance of two test statistics, namely, lambda max and lambda trace for the detection of long-run co-integration. This test is then repeated for the pre-crisis period (from January 2, 2001 to August 8, 2007) and the post-crisis period (from August 9, 2007 to February 24, 2014) in order to see the impact of the crisis on the Johansen results.

This conventional Johansen approach, however, assumes a stable long-run relationship as mentioned in the introduction. A violation of this stability assumption is very likely in case of structural breaks. Then the question of whether there are diversification benefits may be subject to biased interpretations when static methodology is applied to the data if the structural breaks are present.

Under the light of these arguments, we employed dynamic co-integration analysis in order to explicitly control the structural breaks and to empirically assess the time-varying nature of the co-integration relationship. The origins of the dynamic co-integration analysis can be traced to Hansen and Johansen (1992) which suggests a recursively calculated trace test statistic to get an insight into the constancy or non-constancy of co-integration relationships. Hansen and Johansen (1992) investigated the presence of time-varying co-integration by using a trace statistic which is calculated initially over a defined period and then re-calculated again for each of the 
subsequent periods that are constructed as increments to the original period. Pascual (2003), however, indicated that a rolling window approach would be more appropriate because it is based on a fixed number of observations since each window has the same number of observations while the recursive window approach is based on an increasing number of observations. It is argued that (Pascal, 2003; Gilmore et al., 2008) the recursive window approach may lead to statistically less powerful results when the size of the sample in the window increases over time. We adopted the rolling window approach under the light of these arguments.

Following Gilmore et al.(2008) we used a fixed window size of 500 days (approximately 2 years). We moved the window forward one day at a time. This allowed us to calculate the $\lambda$-trace statistic for 500 observations per rolling window which is rolled by adding one observation to the end and removing the first observation. For ease of interpretation, the calculated trace statistics of each window are rescaled by the $95 \%$ quantile of the asymptotic distribution (MacKinnon et al., 1999). The test statistic is then plotted against time. The plotted test statistic provides a visual impression of whether the co-integration relationships are relatively constant over time. If the equilibrium relationship is fairly constant, then the trace statistic is expected to display a fairly constant and linear appearance. Re-scaled values of the trace statistic above 1 indicate that the null of co-integration is rejected in the relevant time period (for the period within the window) while values below 1 suggest no-cointegration and the possibility of diversification benefits. The trace statistics are generated for all the 10 countries in the sample using the full observation set. They yield valuable insight regarding the impact of the crisis (GFC) on the evolution of the co-integration relationship between the REIT and stock market indices for the relevant countries.

Though this tool is basically descriptive in character, it still provides insight for the possible differential effects of the crisis across different countries. A yardstick in that regard is the observation of a trace statistic which is well above 1 for an extended period of time (impyling strong co-integration relationship in that period) versus a trace statistic which is barely over 1 only for a short period of time (implying a weak co-integration relationship). A trace statistic below 1 suggests absence of co-integration in that particular period.

\section{Empirical Results}

The Augmented Dickey-Fuller (ADF) and Phillips-Perron (PP) unit root tests for the full observation period, the pre-crisis period and the post-crisis period confirm that all the log stock indices and log REIT series are I(1) at the $1 \%$ significance level while their first differences are stationary without exception. Both ADF and PP include a constant and a linear time trend. Lag lengths for the ADF and PP tests were selected according to the Schwartz information criterion. The table for unit root test results is not reported here for the sake of bravity.

Table 1a. Descriptive statistics (pre-crisis period)

\begin{tabular}{|c|c|c|c|c|c|c|c|c|c|c|}
\hline \multirow[b]{2}{*}{ Country } & \multicolumn{5}{|c|}{ Stock Index Return } & \multicolumn{5}{|c|}{ Reit Index Return } \\
\hline & Mean & Std. Dev & Skewness & Kurtosis & JB & Mean & Std. Dev & Skewness & Kurtosis & JB \\
\hline Australia & 0.000368 & 0.007000 & -0.536900 & 6.119200 & 757.24 & 0.000328 & 0.007200 & 0.047600 & 4.631400 & 185.82 \\
\hline Belgium & 0.000260 & 0.010100 & 0.156400 & 9.390700 & 2877.68 & 0.000204 & 0.007000 & -0.143000 & 6.408800 & 822.54 \\
\hline Canada & 0.000306 & 0.008100 & -0.447300 & 5.627700 & 533.57 & 0.000488 & 0.008600 & -0.001600 & 8.950000 & 2451.65 \\
\hline France & 0.000075 & 0.012400 & -0.107400 & 6.538500 & & 0.001084 & 0.016300 & 0.137900 & 9.300800 & 2797.55 \\
\hline Germany & 0.000096 & 0.011900 & -0.311300 & 6.075200 & & 0.001905 & 0.029800 & 2.217100 & 25.619600 & 37191.52 \\
\hline Italy & 0.000042 & 0.010800 & -0.432100 & 8.277500 & 1997.17 & 0.000531 & 0.015700 & -0.142800 & 7.419300 & 1369.56 \\
\hline Japan & 0.000335 & 0.011200 & -0.459800 & 4.481600 & 161.03 & 0.000701 & 0.009000 & -0.114800 & 8.675700 & 1708.79 \\
\hline Netherlands & -0.000001 & 0.012700 & -0.130700 & 7.192600 & 1240.39 & 0.000404 & 0.008800 & -0.320200 & 7.789800 & 1641.49 \\
\hline UK & 0.000069 & 0.010300 & -0.296000 & 6.641800 & 946.08 & 0.000467 & 0.010700 & 0.299600 & 9.975900 & 3407.02 \\
\hline US & 0.000120 & 0.010500 & 0.113400 & 6.015200 & 631.25 & 0.000461 & 0.009800 & -0.380000 & 5.065400 & 334.42 \\
\hline
\end{tabular}

Descriptive statistics are calculated using daily log returns of Datastream stock market and REIT indices between January 2, 2001 to August 8, 2007 (for Japan August 9, 2007). JB refers to Jarque-Bera statistics and it rejects normality of all of the series. 
Table 1b. Descriptive statistics (cont.) (post-crisis period)

\begin{tabular}{|c|c|c|c|c|c|c|c|c|c|c|}
\hline \multirow[b]{2}{*}{ Country } & \multicolumn{5}{|c|}{ Stock Index Return } & \multicolumn{5}{|c|}{ Reit Index Return } \\
\hline & Mean & Std. Dev & Skewness & Kurtosis & JB & Mean & Std. Dev & Skewness & Kurtosis & JB \\
\hline Australia & -0.000061 & 0.012700 & -0.396000 & 7.156700 & 1235.48 & -0.000495 & 0.017200 & -0.637800 & 9.042400 & 2631.45 \\
\hline Belgium & -0.000079 & 0.014000 & -0.270200 & 7.360500 & 1349.02 & -0.000022 & 0.010400 & -0.146800 & 12.557200 & 6388.40 \\
\hline Canada & 0.000028 & 0.013300 & -0.620700 & 11.456700 & 4998.34 & 0.000042 & 0.011800 & -0.634300 & 13.166900 & 7182.02 \\
\hline France & -0.000084 & 0.014700 & 0.034700 & 8.222900 & 1905.31 & -0.000086 & 0.013500 & -0.247100 & 5.565600 & 476.71 \\
\hline Germany & 0.000017 & 0.014100 & 0.621600 & 17.088300 & 13876.72 & -0.000572 & 0.029500 & 0.088400 & 23.711200 & 29760.95 \\
\hline Italy & -0.000340 & 0.016400 & -0.034600 & 6.830200 & 1015.04 & -0.000360 & 0.023700 & -0.080300 & 6.547800 & 872.39 \\
\hline Japan & -0.000180 & 0.015900 & -0.408800 & 9.575000 & 2928.43 & -0.000240 & 0.018400 & -0.285200 & 9.901400 & 3198.96 \\
\hline Netherlands & -0.000192 & 0.014800 & -0.307600 & 9.324300 & 2821.22 & -0.000340 & 0.016800 & -0.305000 & 5.575400 & 489.44 \\
\hline UK & 0.000061 & 0.013900 & -0.157700 & 8.800200 & 2325.35 & -0.000250 & 0.019300 & -0.206100 & 6.230000 & 730.72 \\
\hline US & 0.000150 & 0.015100 & -0.318300 & 10.836700 & 4242.37 & -0.000037 & 0.027300 & -0.064800 & 12.280100 & 5911.14 \\
\hline
\end{tabular}

Descriptive statistics are calculated using daily log returns of Datastream stock market and REIT indices between January 9, 2001 (for Japan August 10, 2007) to February 24, 2014. JB refers to Jarque-Bera statistics and it rejects normality of all of the series.

Table 1 reports the basic statistics of the pre-crisis period and the post-crisis period. During the pre-crisis period, the means of stock index returns were positive in all the countries except the Netherlands where the mean was slightly negative. The highest mean values are observed in Australia, Japan and Canada followed by Belgium whereas the means of the U.S., Germany, France, the U.K. and Italy are somewhat lower. All the countries in the sample also display positive REIT return means during the pre-crisis period with the highest means observed in Germany and France. Jacque-Bera statistics rejects the null hypothesis of normal distribution in all the countries.

Stock market returns were negative in Australia, Belgium, France, Italy, Japan and the Netherlands during the post-crisis period with the biggest negative mean in Italy followed by the Netherlands and Japan. However the means were positive in Canada, Germany, the U.K. and the U.S. in the post-crisis period. Compared to the pre-crisis period, the means of stock market returns were lower in all the countries except the U.S. where the mean return increased despite the fact that the subprime crisis originated from this country. The standard deviations are higher in all the countries during the post-crisis period compared to the pre-crisis period. The two major bank-based countries (France and Germany) display markedly different characteristics in their third and fourth moments after the crisis. They both display positive skewness in the post-crisis period and an exceptionally high kurtosis value (17.088 for Germany) while all the other countries have negatively skewed returns in the post-crisis period.

The impact of the crisis on REIT returns and volatiliy was more significant. The mean returns were negative in all the countries during the post-crisis period (with the exception of Canada). The REIT returns declined in all the countries including Canada. The volatility of REIT returns increased very significantly after the crisis (an increase ranging between 50\% and 178\%). The biggest increase is observed in the U.S. where the standard deviation of REIT returns increased by 1.78 times compared to the pre-crisis period. Germany and France, however, display lower standard deviations in the post-crisis period and the REIT returns of Germany displays positive skewness while all the others are characterized by a negative skewness in the post-crisis period. The leading role of the real estate problems in the crisis shows itself in the differential response of REIT volatility with respect to the stock market volatility. The standard deviation of the stock market returns increased $40.8 \%$ (on average) after the crisis while the average increase in the standard deviation of REIT returns was $83.02 \%$.

Table 2. Johansen co-integration test (whole period)

\begin{tabular}{|c|c|c|c|c|c|}
\hline & \multicolumn{2}{|c|}{ Trace } & \multicolumn{2}{|c|}{ Maximum Eigenvalue } & \multirow[b]{2}{*}{ Lag } \\
\hline & $\mathrm{r}=0$ & $\mathrm{r} \leq 1$ & $\mathrm{r}=0$ & $\mathrm{r} \leq 1$ & \\
\hline \multirow[t]{2}{*}{ Australia } & 4.081 & 0.325 & 3.756 & 0.325 & 11 \\
\hline & $(0.897)$ & $(0.569)$ & $(0.884)$ & $(0.569)$ & \\
\hline \multirow[t]{2}{*}{ Belgium } & 13.242 & 1.877 & 11.365 & 1.877 & 8 \\
\hline & (0.106) & $(0.171)$ & $(0.137)$ & $(0.171)$ & \\
\hline \multirow[t]{2}{*}{ Canada } & 10.634 & 1.908 & 8.726 & 1.908 & 11 \\
\hline & $(0.235)$ & $(0.167)$ & $(0.310)$ & $(0.167)$ & \\
\hline \multirow[t]{2}{*}{ France } & 19.271 & 8.668 & 10.603 & 8.668 & 6 \\
\hline & $(0.265)$ & $(0.202)$ & $(0.555)$ & $(0.202)$ & \\
\hline
\end{tabular}




\begin{tabular}{|c|c|c|c|c|c|}
\hline \multirow[t]{2}{*}{ Germany } & 16.397 & 2.804 & 13.593 & 2.804 & 11 \\
\hline & $(0.461)$ & $(0.899)$ & $(0.283)$ & (0.899) & \\
\hline \multirow[t]{2}{*}{ Italy } & 12.475 & 2.466 & 10.009 & 2.466 & 10 \\
\hline & $(0.136)$ & $(0.116)$ & $(0.211)$ & $(0.116)$ & \\
\hline \multirow[t]{2}{*}{ Japan } & 15.644 & 1.630 & 14.014 & 1.630 & 9 \\
\hline & (0.048) & $(0.202)$ & $(0.055)$ & $(0.202)$ & \\
\hline \multirow[t]{2}{*}{ Netherlands } & 14.527 & 3.948 & 10.578 & 3.948 & 8 \\
\hline & (0.614) & $(0.750)$ & $(0.557)$ & $(0.750)$ & \\
\hline \multirow[t]{2}{*}{ UK } & 3.785 & 1.752 & 2.033 & 1.752 & 8 \\
\hline & $(0.920)$ & $(0.186)$ & $(0.990)$ & $(0.186)$ & \\
\hline \multirow[t]{2}{*}{ US } & 10.403 & 0.797 & 9.606 & 0.797 & 11 \\
\hline & $(0.251)$ & $(0.372)$ & $(0.239)$ & $(0.372)$ & \\
\hline
\end{tabular}

P-values are provided in parentheses. Lag order is chosen such that the error terms are serially uncorrelated and the Akaike Information Criterion (AIC) is minimized. The observation period is from January 2, 2001 to February 24, 2014. Critical values are provided by MacKinnon et al. (1999). ***,**, and $*$ indicate significance at $1 \%, 5 \%$ and $10 \%$ level, respectively.

Table 3. Johansen co-integration test (pre-crisis period)

\begin{tabular}{|c|c|c|c|c|c|c|c|}
\hline & \multicolumn{3}{|c|}{ Trace } & \multicolumn{3}{|c|}{ Maximum Eigenvalue } & \multirow[b]{2}{*}{ Lag } \\
\hline & $\mathrm{r}=0$ & & $\mathrm{r} \leq 1$ & $\mathrm{r}=0$ & & $r \leq 1$ & \\
\hline \multirow[t]{2}{*}{ Australia } & 8.237 & & 0.018 & 8.219 & & 0.018 & 8 \\
\hline & $(0.440)$ & & $(0.894)$ & $(0.357)$ & & $(0.894)$ & \\
\hline \multirow[t]{2}{*}{ Belgium } & 11.854 & & 1.531 & 10.323 & & 1.531 & 3 \\
\hline & $(0.164)$ & & $(0.216)$ & $(0.192)$ & & $(0.216)$ & \\
\hline \multirow[t]{2}{*}{ Canada } & 16.455 & & 0.062 & 16.394 & & 0.062 & 1 \\
\hline & $(0.036)$ & $* *$ & $(0.804)$ & $(0.023)$ & $* *$ & $(0.804)$ & \\
\hline \multirow[t]{2}{*}{ France } & 15.916 & & 2.141 & 13.775 & & 2.141 & 8 \\
\hline & $(0.043)$ & $* *$ & $(0.143)$ & $(0.060)$ & $*$ & $(0.143)$ & \\
\hline \multirow[t]{2}{*}{ Germany } & 17.132 & & 0.257 & 16.875 & & 0.257 & 8 \\
\hline & $(0.028)$ & $* *$ & $(0.612)$ & $(0.019)$ & $* *$ & $(0.612)$ & \\
\hline \multirow[t]{2}{*}{ Italy } & 12.605 & & 0.325 & 12.280 & & 0.325 & 10 \\
\hline & $(0.130)$ & & $(0.569)$ & $(0.101)$ & & $(0.569)$ & \\
\hline \multirow[t]{2}{*}{ Japan } & 7.239 & & 0.000 & 7.239 & & 0.000 & 1 \\
\hline & $(0.550)$ & & $(0.988)$ & $(0.461)$ & & $(0.988)$ & \\
\hline \multirow[t]{2}{*}{ Netherlands } & 11.717 & & 2.486 & 9.232 & & 2.486 & 10 \\
\hline & $(0.171)$ & & $(0.115)$ & $(0.267)$ & & $(0.115)$ & \\
\hline \multirow[t]{2}{*}{ UK } & 9.624 & & 1.134 & 8.490 & & 1.134 & 4 \\
\hline & $(0.311)$ & & $(0.287)$ & $(0.331)$ & & $(0.287)$ & \\
\hline \multirow[t]{2}{*}{ US } & 10.668 & & 0.690 & 9.978 & & 0.690 & 2 \\
\hline & $(0.233)$ & & $(0.406)$ & $(0.213)$ & & $(0.406)$ & \\
\hline
\end{tabular}

P-values are provided in parentheses. Lag order is chosen such that the error terms are serially uncorrelated and the Akaike Information Criterion (AIC) is minimized. The observation period is from January 2, 2001 to August 8, 2014 (for Japan August 9, 2001). Critical values are provided by MacKinnon et al. (1999). ***,**, and * indicate significance at $1 \%, 5 \%$ and $10 \%$ level, respectively.

Table 4. Johansen co-integration test (post-crisis period)

\begin{tabular}{|c|c|c|c|c|c|c|}
\hline & \multicolumn{3}{|c|}{ Trace } & \multicolumn{2}{|c|}{ Maximum Eigenvalue } & \multirow[b]{2}{*}{ Lag } \\
\hline & $\mathrm{r}=0$ & & $\mathrm{r} \leq 1$ & $r=0$ & $\mathrm{r} \leq 1$ & \\
\hline \multirow[t]{2}{*}{ Australia } & 18.875 & & 5.163 & 13.712 & 5.163 & 11 \\
\hline & $(0.288)$ & & $(0.573)$ & $(0.274)$ & $(0.573)$ & \\
\hline \multirow[t]{2}{*}{ Belgium } & 28.666 & & 8.703 & 19.963 & 8.703 & 8 \\
\hline & $(0.022)$ & $* *$ & $(0.199)$ & $(0.041) \quad * *$ & (0.199) & \\
\hline \multirow[t]{2}{*}{ Canada } & 5.308 & & 0.878 & 4.430 & 0.878 & 11 \\
\hline & $(0.775)$ & & $(0.349)$ & $(0.812)$ & $(0.349)$ & \\
\hline \multirow[t]{2}{*}{ France } & 14.424 & & 5.804 & 8.620 & 5.804 & 5 \\
\hline & $(0.623)$ & & $(0.486)$ & $(0.763)$ & $(0.486)$ & \\
\hline \multirow[t]{2}{*}{ Germany } & 9.668 & & 0.497 & 9.170 & 0.497 & 11 \\
\hline & $(0.307)$ & & $(0.481)$ & $(0.272)$ & $(0.481)$ & \\
\hline
\end{tabular}




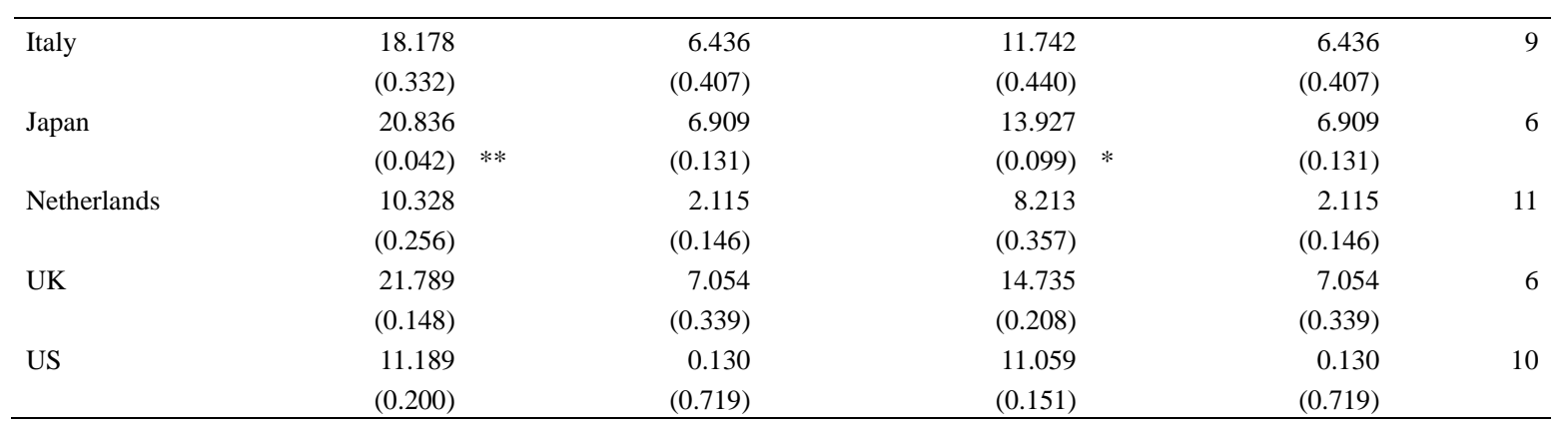

P-values are provided in parentheses. Lag order is chosen such that the error terms are serially uncorrelated and the Akaike Information Criterion (AIC) is minimized. The observation period is from August 9, 2001 (for Japan August 10, 2001) to February 24, 2014. Critical values are provided by MacKinnon et al. (1999). ***,**, and * indicate significance at 1\%, 5\% and $10 \%$ level, respectively.

Table 2, Table 3 and Table 4 present the results of the conventional static Johansen co-integration test for the full observation period, pre-crisis period and the post-crisis period respectively. The null hypothesis of no co-integration cannot be rejected for the nine countries in the sample for the full observation period. The only exception is Japan which is the only country that displays a co-integration relationship in the full observation period (Note 3). In the pre-crisis period, there is an evidence of Johansen co-integration in Canada, Germany and France (but not in Japan) (Note 4). In the post-crisis period; we can find evidence of Johansen co-integration only in Belgium and Japan despite the well known fact of increased correlations between the REIT and stock indices after the crisis. Conventionally; the lack of co-integration for most of the countries in the sample suggests the existence of long-term diversification benefits between these two markets which may, however, be a pre-mature statement without further exploring the reasons for the negative results of Johansen co-integration test.
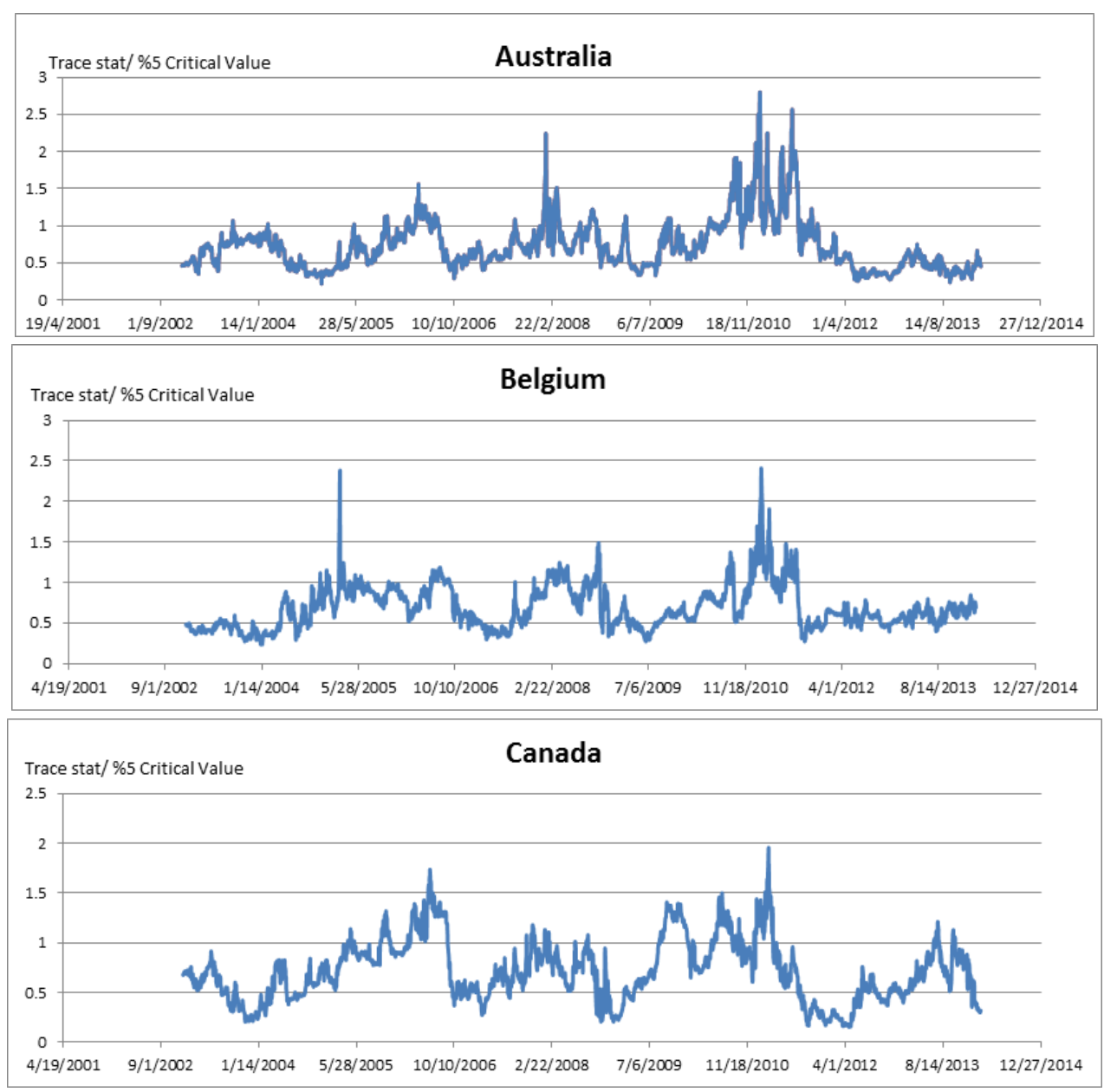

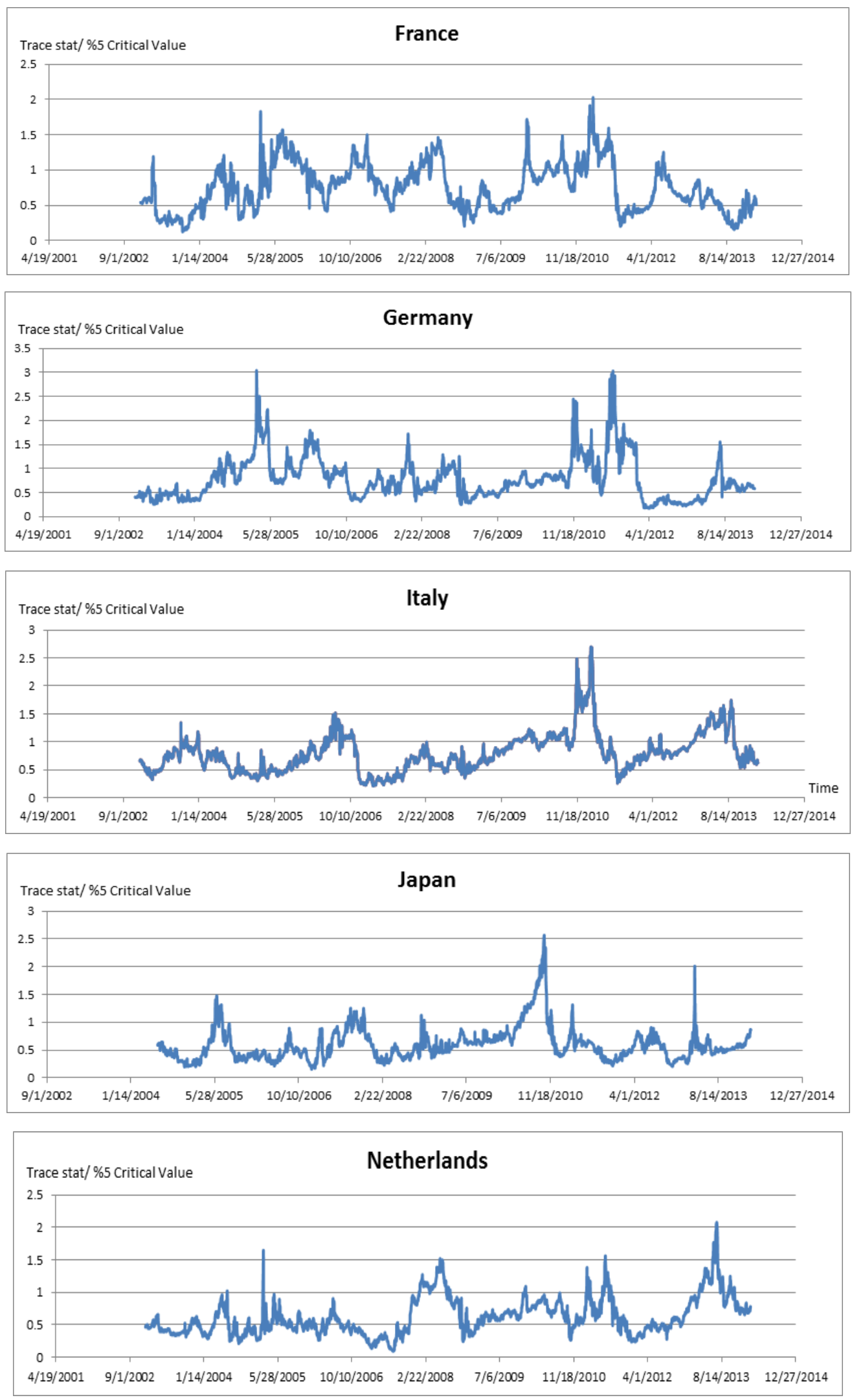


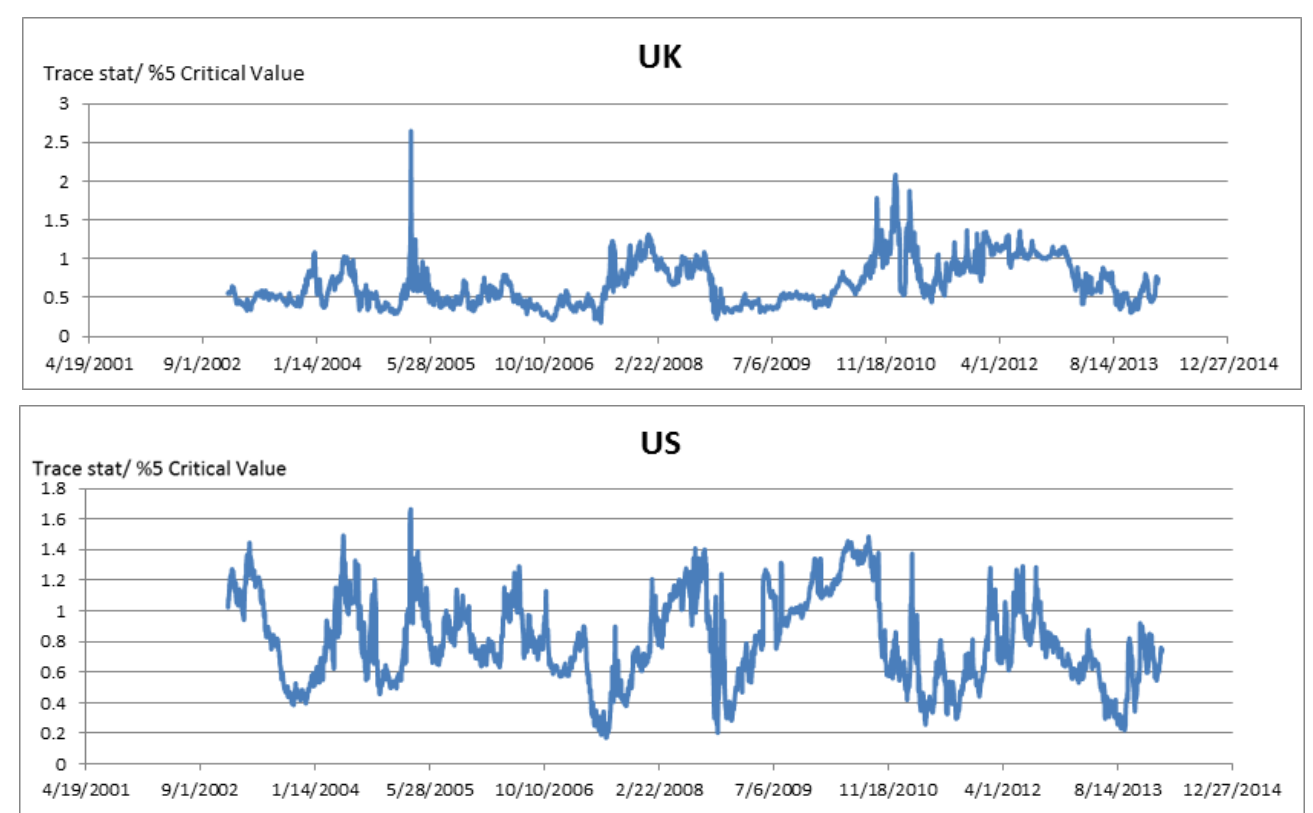

Figure 1. 500 Day rolling- window standardized trace statistic

Note. The lambda trace statistics are by the $95 \%$ quantile of the asymptotic distribution (MacKinnon et al., 1999). Re-scaled values of the trace statistic above 1 indicate that the null of co-integration is rejected in the relevant time period (for the period within the window) while values below 1 suggest no-cointegration.

Figure 1 displays the the normalized trace statistics for the ten countries in the sample. This dynamic approach based on a rolling window suggests a co-integration relationship in the relevant period if the normalized trace statistic is over 1 and rejects co-integration if it is less than 1 . A common feature of all the diagrams is the highly variable nature of the normalized trace statistics which are below 1 at certain periods but over 1 in the other periods. This strongly suggests a time-varying co-integration relationship which may partially explain the negative results of the static Johansen test. The U.S. is particularly characterized by a very volatile relationship.

An inspection of the normalized trace statistics in Figure 1 with an emphasis on their evolution over time highlights the fact that they tend to be less than 1 in most countries prior to the GFC 2007. The only exceptions are France, Germany and Canada whose trace statistics are over 1 for a considerable time (mainly during 2005) in this pre-crisis period. This observation is consistent with the results of the static Johansen test in Table 3 which finds co-integration for these three countries but not for the others. We do not observe any contradiction between the results of the static Johansen test and the dynamic co-integration approach during the pre-crisis period before the onset of the GFC. The case of the U.S., however, is somewhat of an enigma where the trace statistics above 1 are observed before 2007 but there is no evidence of conventional Johansen co-integration in the same period. This discrepancy may be due to the extremely volatile nature of the relationship between stock and REIT indices in the U.S.

The normalized trace statistics of all the countries (except Italy) starts moving over 1 during the second half of 2007 which obviously is related to the subprime crisis in that period. A closer inspection of the charts in Figure 1 suggests that the response patterns differ somewhat across the countries in the sample. The trace statistics of the U.S., Australia, France and the Netherlands are well over 1 in the latter half of 2007 and for most of 2008. On the other hand; the trace statistics of Belgium, Canada, the U.K. and Germany are only slightly over 1 during the same period. The trace statistic of Japan move over 1 briefly in the second half of 2007 but stay below 1 for whole of 2008 despite the Lehman incident. This implies that although almost all countries in the sample responded to the onset of the GFC by displaying an increase in the correlations between their REIT and stock index futures; the impact was stronger and more accentuated for the group mentioned above.

The trace statistics of all the countries start moving below 1 by early 2009 indicating that the impact of the shock associated with the subprime crisis started to dissipate by that time. They stay below 1 for the rest of 2009 and for most of 2010 in a large group including the U.K., the Netherlands, Australia, Belgium, Italy, Germany and Japan. The exceptions are the U.S. and Canada (to a lesser degree France) which continue to display trace statistics well over 1 during the second half of 2009 and early 2010 (Note 5). 
A most noteworthy fact that we observe in Figure 1 is the sudden jump in the trace statistics of all the countries which starts by November 2010. This sudden jump is valid for all the countries in the sample without exception strongly suggesting a common factor that initiated it. As is well known; November 2010 is the date when Greece asked for a bailout leading to a second shock associated with the European insolveny problems. The evolution of the trace statistics over time implies that there were indeed two successive shocks. The first shock that started in mid 2007 was directly related to the U.S. based subprime crisis affecting the U.S. more as expected. The effects of this first shock was almost over by early 2009. Then a second shock followed by November 2010 as a result of European debt crisis. Both crises led to a marked increase in the correlations between REIT and stock indices for all the countries in the sample. When we check the length of time during which trace statistics stay above 1 and how far they are above 1, we observe that the dynamic co-integrations associated with the second shock were characterically higher in the Eurozone group of Germany, France, Italy and Belgium. In fact; the dynamic co-integrations for this Eurozone group were visibly higher during the second shock compared to the first shock suggesting that this group's response to the subprime crisis was relatively weak while its response to the European debt related shock was particularly strong. The non-European countries of the sample including the U.S., Canada, Japan and Australia also display normalized trace statistics moving over 1 by late 2010 (though the effect on Japan was weaker). The overall picture suggests that there was indeed not one shock but rather two consecutive shocks leading to strong correlations between the REIT and stock indices of all the sampled countries.

In most of the countries; dynamic co-integration starts to disappear by the early 2011 and the trace statistics move below 1 in that period (Note 6). Italy and the Netherlands somewhat deviate from this general trend displaying evidence of dynamic co-integration during mid-2013. This may be due to the specific domestic problems in the case of Italy. The trace statistics of all the ten countries, however, are below 1 by the end of 2013 which do suggest that the effects of the two successive crises were over by that time.

The normalized trace statistics clearly imply a strong co-integration relationship after the onset of the crisis which is not detected by the static Johansen tests. The similarity that we observe between the results of the static Johansen test and the results of the dynamic co-integration in the pre-crisis period vanishes after the crisis. The overall empirical evidence strongly suggests that the two major shocks stemming from the U.S. subprime problems and the European insolvency problems led to a structural break in the data. The conventional Johansen tests were not able to detect the strong co-integration implied by the normalized trace statistics which is clearly observed in Figure 1. This failure can be explained by the low power of the conventional tests due to structural breaks in a time-varying co-integration context (Note 7).

Our empirical results are mostly in line with some of the recent literature including Luctenberg and Seiler (2014) which presents evidence of no-cointegration prior to the crisis (for the U.S. indices) but a strong correlation after the crisis and Liow and Schindler (2014) presenting evidence for the time-varying nature of the co-integration relationships and the structural change after the crisis using a sample of countries similar to the one used in this study.

A plausible explanation of what happened during the crisis period may be the following: The investors were suddenly faced with an unprecented shock stemming from the real estate market. This extreme shock and the associated fear psychology led to a flight from both markets leading to the observed strong correlations between the stock and REIT markets. The first subprime related shock was more effective in North America and less in Europe. The visible effects of this first shock started to decrease by 2009 but the markets were then faced with a second big shock by late 2010 due to the serious liquidity and solvency problems in Europe. This initiated a second phase of flight from both markets which was felt more acutely in Eurozone countries. These two crises led to a global increase in the correlation between the REIT and stock returns. This observed correlation, however, was not due to the conventional wealth and credit effects. It was rather the result of a joint negative response of both markets to these successive shocks.

The evidence presented so far implies that REIT markets may provide diversification benefits in the long-run in the absence of major shocks. The evidence of co-integration in normal times is weak. We cannot detect conventional co-integration in most of the countries prior to the crisis. The normalized trace statistics are also below 1 in the majority of the countries during the pre-crisis period suggesting absence of dynamic co-integration as well. Those statistics which are visibly above 1 during the crisis period of 2007-2012 revert back to values below 1 apparently as the effects of the shocks dissipate over time. The destruction of the diversification benefits seem to be an event confined to the crisis period. 


\section{Conclusions}

In this paper, we investigated the impact of the Global Financial Crisis (GFC) on the co-integration relationship between the stock and REIT indices using a sample of ten developed countries and daily data. The data and our analysis strongly imply that there were two successive major shocks with a deep negative impact on both REIT and stock markets. The first shock was associated with the U.S. subprime crisis. The second shock was due to the European debt and insolvency problems.

We were unable to detect co-integration in most of the countries using conventional and static Johansen tests. This result was valid for the whole observation period (except Japan) as well as for the pre-crisis and post-crisis period. However; we detected significant co-integration when we used a dynamic co-integration approach based on a moving window of 500 observations. This apparent contradiction can be explained by the low power of conventional tests in periods dominated by shocks since these shocks lead to structural breaks in the data and a highly varying correlation structure over time.

Our overall results imply that the REIT markets may still provide long-term diversification benefits despite increasing globalization if the markets operate normally in the absence of major shocks. The strong correlations observed between the REIT and stock indices constraining diversification after the onset of the GFC was rather the the result of a common flight from both markets during the crisis dominated 2007-2012 period.

\section{References}

Adair, A., Berry, J., Lloyd, M., \& Mcgreal, S. (2009). The Global Financial Crisis: Impact on Property Markets in the UK and Ireland. Research Report; University of Ulster. Retrieved from https://pdfs.semanticscholar.org/0968/760dbf0f4875b931dc89a538772ef73210a2.pdf

Ambrose, B., Angel, E., \& Griffits, M. (1992). The Fractal Structure of Real Estate Investment Trust Returns: A Search for Evidence of Market Segmentation and Nonlinear Dependency. Journal of American Real Estate and Urban Economic Association, 20, 25-54. https://doi.org/10.1111/1540-6229.00571

Assaf, A. (2006). REIT's and Stock Prices: Fractional Co-integration and Long Memory. Review of Pacific Basin Financial Markets and Policies, 9(3), 441-462. http://dx.doi.org/10.1142/S0219091506000793

Barker, D. (2009). Plunder and Blunder. Sausalito CA: Polipoint Press.

Basse, T. F, Meik, F., \& Eduardo, V. B. (2009). REIT's and Financial Crisis: Empirical Evidence from the U.S. International Journal of Business and Management, 4(11), 3-7. http://dx.doi.org/10.5539/ijbm.v4n11p3

Casni, A. C., \& Vizek, M. (2014). Interactions between Real Estate and Equity Markets: An Investigation of Linkages in Developed and Emerging Countries. Czech Journal of Economics and Finance, 64(2), 100-119.

Devaney, M. (2012). Financial Crisis, REIT Short Sell Restrictions and Event Induced Volatility. Quarterly Review of Economics and Finance, 52, 219-226. https://doi.org/10.1016/j.qref.2012.04.003

Devos, E., Ong, S. E., Spieler, A. C., \& Tsang, D. (2013). REIT Institutional Ownership Dynamics and Financial Crisis. Journal of Real Estate Finance and Economics, 47(2), 266-288. https://doi.org/10.1007/s11146-012-9363-2

Gilmore, C. G., Lucey, B. M., \& McManus, G. M. (2008). The Dynamics of Central European Equity Market Comovements. The Quarterly Review of Economics and Finance, 48, 605-622. https://doi.org/10.1016/j.qref.2006.06.005

Glascock, J. L., Lu, C., \& So, R. W. (2000). Further Evidence on the Integration of REIT, Bond and Stock Returns. Journal of Real Estate Finance and Economics, 20, 177-194. https://doi.org/10.1023/A:1007877321475

Glascock, J., Michayluk, D., \& Neuhauser, K. (2004). The Riskiness of REIT's Surrounding the October 1997 Stock Market Decline. Journal of Real Estate Finance and Economics, 28, 339-354. https://doi.org/10.1023/B:REAL.0000018786.39272.fa

Gordon, J., \& Canter, T. (1999). Institutional Real Estate Securities: A Test of Capital Market Integration. Journal of Real Estate Portfolio Management, 5(2), 161-170.

Gregory, A. W., \& Hansen, B. E. (1996). Residual Based Tests for Co-Integration in Models with Regime Shifts. Journal of Econometrics, 70, 99-126. https://doi.org/10.1016/0304-4076(69)41685-7

Guidi, F., \& Ugur, M. (2014). An Analysis of South-Eastern Stock Markets: Evidence of Co-Integration and Portfolio Diversification Benefits. Journal of International Markets, Institutions and Money, 30, 119-136. 
Hall, S. G. (1989). Maximum Likelihood Estimation of Cointegration Vectors: An Example of the Johansen Procedure. Oxford Bulletin of Economics and Statistics, 51, 213-218. https://doi.org/10.1111/j.1468-0084.1990.mp52002003.x

Hansen, H., \& Johansen, S. (1992). Recursive Estimation in Co-Integrated VAR Models. Discussion Paper, Institute of Economics, University of Copenhagen, pp. 92-113.

Hoesli, M., \& Okarinen, E. (2012). Are REIT's Real Estate? Evidence from International Level Data. Journal of International Money and Finance, 3, 1823-1850. https://doi.org/10.1016/j.jimonfin.2012.05.017

Ibbotson, R. G., \& Siegel, L. B. (1984). Real Estate Returns: A Comparison with Other Instruments. Real Estate Economics, 12(3), 219-241. https://doi.org/10.1111/1540-6229.00320

Johansen, S. (1988). Statistical Analysis of Co-Integration Vectors. Journal of Economic Dynamics and Control, 12, 231-254. https://doi.org/10.1016/0165-1889(88)90041-3

Lin, T. C., \& Lin, Z. H. (2011). Are Stock and Real Estate Markets Integrated? An Empirical Study of Six Asian Economies. Pacific Basin Finance Journal, 19, 571-585. https://doi.org/10.1016/j.pacfin.2011.05.001

Ling, D., \& Naranjo, A. (1999). The Integration of Commercial Real Estate Markets and Stock Markets. Real Estate Economics, 27(3), 1-28. https://doi.org/10.1111/1540-6229.00781

Liow, K. H., \& Schindler, F. (2014). An Asssessment of the Relationship between Public Real Estate and Stock Markets at the Local, Regional and Global Levels. International Real Estate Review, 17(2), 157-202.

Liu, C. H., Hartzell, D. J., Creig, W., \& Grissom, T. V. (1990). The Integration of the Real Estate and the Stock Market: Some Preliminary Evidence. Journal of Real Estate Finance and Economics, 3, 261-282. https://doi.org/10.1007/bf00216190

Liu, Y., \& Mei, J. (1992). The Predictability of Returns on Equity REIT's and Their Co-Movements. Review of Financial Economics, 18(2), 80-89.

Longin, F., \& Solnik, B. (1995). Is the Correlation in International Equity Returns Constant: 1960-1990? Journal of International Money and Finance, 14(1), 3-26. https://doi.org/10.1016/0261-5606(94)00001-H

Luctenberg, K. F., \& Seiler, M. J. (2014). Did the Recent Financial Crisis Impact Integration between Real Estate and Stock Markets. Journal of Real Estate Portfolio Management, 20(1), 1-20.

MacKinnon, J. G., Haug, A. A., \& Michelis, L. (1999). Numerical Distribution Functions of Likelihood Ratio Tests for Cointegration. The Journal of Applied Econometrics, 15, 563-577. https://doi.org/10.1002/(SICI)1099-1255(199909/10)14:5<563::AID-JAE530>3.0.CO;2-R

Miles, M., Cole, R., \& Guikey, D. (1990). A Different Look at Commercial Real Estate Returns. Journal of American Real Estate and Urban Economic Association, 18, 403-440. https://doi.org/10.1111/1540-6229.00530

Pascual, A. G. (2003). Assessing European Stock Market Integration. Economic Letters, 78, 197-203. http://doi.org/10.1016/S0165-1765(02)00245-8

Peng, L., \& Schulz, R. (2013). Does the Diversification Potential of Securitized Real Estate Vary over Time and Should Investors Care. Journal of Real Estate Finance and Economics, 47(2), 310-340. https://doi.org/10.1007/s11146-011-9357-5

Quan, D. C., \& Titman, S. (1999). Do Real Estate Prices and Stock Prices Move Together? An International Analysis. Real Estate Economics, 27(2), 183-207. https://doi.org/10.1111/1540-6229.00771

Schindler, F., \& Voronkova, S. (2010). Linkages between International Securitized Real Estate Markets: Further Evidence from Time-Varying and Stochastic Co-Integration. Discussion Paper, Zentrum für Europaische Wirtschaftsforshung-Mannheim. https://doi.org/10.2139/ssrn.1663635

Wilson, P. J., \& Zurbruegg, R. (2003). International Diversification of Real Estate Assets: Is It Worth It? Evidence from the Literature. Journal of Real Estate Literature, 11(3), 257-278. https://doi.org/10.2139/ssrn.882001

Yang, J., Yinggang, Z., \& Leung, W. K. (2012). Asymmetric Correlation and Volatility Dynamics among Stock,Bond and Securitized Real Estate Markets. Journal of Real Estate Finance and Economics, 45(2), 491-521. https://doi.org/10.1007/s11146-010-9265-0 


\section{Notes}

Note 1. The conventional tests have also low power in detecting co-integration when the series are strongly correlated but also characterized by a non-linear structure. In such cases; the use of alternative tools such as M-TAR is suggested to detect co-integration. We are currently working on a paper which deals with the co-integration between the REIT and stock indices in the presence of non-linear adjustment towards long-run equilibrium. The emphasis of this paper, however, is to focus on the altered dynamics of the relationship between REIT and stock indices as a result of the GFC related structural breaks.

Note 2. This date is suggested in several earlier studies. Some studies, however, used the delisting of Lehman Brothers on September 7, 2008 as the relevant cutoff point. We have not adopted this approach for two reasons. First, there is quite convincing empirical evidence (mentioned in the introduction) which shows that there was a structural break during 2007. Yang et al. (2012), for example, demonstrates a structural break on July 31, 2007 using Chow test which is a date very close to the one adopted by us. Also, the uptrend of S\&P500 index was already over by the end of July 2007 indicating growing concerns in the market.

Note 3. Lin and Lin (2011) also finds evidence of co-integration in Japan.

Note 4. Note that Germany and France are bank-based financial systems which may imply that the long- term correlations between stock and REIT indices tend to be stronger in bank-based countries in the absence of big shocks.

Note 5. A possible explanation of this fact which suggests an increasing correlation between the REIT and stock indices of the U.S. and Canada in the latter half of 2009 may be the following: Looking to the charts of the DJ world index and the world REIT index, we see that the downtrend was over by March 2009 which was then followed by a bullish reaction in both indices which may plausibly explain the observed correlation in that period.

Note 6. The U.S. and the U.K. , however, display a belated normalization whose trace statistics starts falling below 1 by the end of 2012 .

Note 7. We have further evidence showing that the co-integration relationship after the crisis was markedly different than the pre-crisis period. In another study; we have found evidence of co-integration in all the countries during the second subperiod by using M-TAR model. The third subperiod is also characterized by M-TAR co-integration in most of the countries. This strongly imply a non-linear adjustment process caused by the GFC shock.

\section{Copyrights}

Copyright for this article is retained by the author(s), with first publication rights granted to the journal.

This is an open-access article distributed under the terms and conditions of the Creative Commons Attribution license (http://creativecommons.org/licenses/by/4.0/). 